\title{
Effects of pine honey on the physicochemical, microbiological and sensory properties of probiotic yoghurt
}

\author{
Fatma COSKUN $^{1 \star}$ (D), Leyla KARABULUT DIRICAN ${ }^{1}$
}

\begin{abstract}
In this study, physicochemical, microbiological and sensory properties of probiotic yoghurt samples added different rates $(2 \%, 4 \%$ and $6 \%)$ of pine honey on days $1,7,14,21$ of refrigerated storage were investigated. $\mathrm{pH}$, serum separation values, water holding capacity decreased and titratable acidity increased with increasing the ratio of the added honey during the storage. Lactobacillus. delbrueckii ssp. bulgaricus and Lactobacillus acidophilus counts were statistically significantly $(\mathrm{P}<0.01)$ lower than control samples in honey added yoghurt samples from the beginning to the end of storage. Streptococcus thermophilus counts did not change much during storage and were higher than control samples in yoghurt samples with honey from the beginning. The brightness $\left(\mathrm{L}^{*}\right)$ decreased with increasing honey ratio. The $\mathrm{a}^{*}$ and $\mathrm{b}^{*}$ values of all honey-added yoghurt samples were higher than those without honey. Although yoghurt with $2 \%$ pine honey had the same points as the yoghurt with $4 \%$ pine honey in terms of some sensory properties, it was the most liked yoghurt. For people who do not like to consume plain yoghurt, honey added yogurt can be a good alternative functional food. Producers should produce formulations for this type of yogurt and the consumption of yogurt should be increased.
\end{abstract}

Keywords: honey; pine honey; honey-added yoghurt; probiotic yoghurt.

Pratica Application: Yoghurt production by adding probiotic bacteria and pine honey into yoghurt milk and investigation of the properties of this yoghurt.

\section{Introduction}

Yoghurt is one of the most popular fermented dairy products worldwide, which has great consumer acceptability due to its health benefits other than its basic nutrition (Weerathilake et al., 2014). It is traditionally made from the spontaneous or induced lactic acid fermentation of milk (Widyastuti et al., 2014; Fazilah et al., 2018). Basically, yogurt can be classified into two groups, which are standard culture yogurt and bioyogurt or probiotic yogurt (Pandey et al., 2017; Fazilah et al., 2018). Standard yogurt is typically manufactured from the conventional starter culture strains, $L b$. delbrueckii ssp. bulgaricus and S. thermophilus (Arena et al., 2015; Fazilah et al., 2018). Meanwhile bio-yogurt or probiotic yogurt is supplemented with probiotic strains such as Bifidobacterium and $L b$. acidophilus that are claimed to have numerous health benefits and should remain live at adequate numbers (Chen et al., 2017; Fazilah et al., 2018). Yogurt is considered as the most popular vehicle for the delivery of probiotics for the consumers (Lourens-Hattingh \& Viljoen, 2001). An increasing number of studies have indicated the health benefits related to their regular consumption (Akalın et al., 2012; Cruz et al., 2013).

Benefits of probiotic products are: strengthening of the immune system; protection of normal intestinal microflora; reduction of lactose intolerance; exhibiting anticancerogenic effect; ensuring that serum cholesterol levels remain constant; prevention of osteoporosis, antibiotic-induced diarrhea and urogenital infections; improve the nutritional value of food, prevention of hypercholesterolemia and infantile diarrhea, relief of constipation, protection against colon / bladder cancer (Fuller, 1989). The ability of probiotic bacteria to survive during food storage and to benefit consumers is a difficult process for the food industry. Acidity occurring in especially yogurt, exposure to oxygen and low temperatures during storage may cause adverse effects on the survival of such microorganisms. This may cause commercial products not to be useful (Granato et al., 2010; Batista et al., 2015). Yoghurt must contain at least $10^{6}$ to $10^{8} \mathrm{cfu} / \mathrm{g}$ of live bacteria during consumption according to the food laws of many countries (Codex Alimentarius Hungaricus, 2004; Varga, 2006).

Maintaining the viability of probiotics during the passage of intestines in production and storage is the primary reason for choosing the appropriate probiotic. Lactobacilli are generally more resistant than Bifidobacteria compared to their response to different factors (Akan \& Kınık 2015). Selection criteria of probiotic strains must also considered the possible interactions among strains and dairy products as well as starter culture bacteria to optimise their performance and survival during storage (Casarotti et al., 2014; Fazilah et al., 2018).

Some probiotic bacteria grow slowly in milk due to lack of essential proteolytic activity and their acidifying characteristic may affect the product texture (Lucas et al., 2004). In comparison to yogurt starter culture, probiotic bacteria are often having a poor acidification performance in milk (Almeida et al., 2008). The addition of probiotic culture can reduce the acid accumulation 
during storage period (Kailasapathy, 2006). Furthermore, post exopolysaccharides have been observed in yogurts supplemented with probiotic cultures compared to yogurt without probiotics (Fazilah et al., 2018)

Plain dairy products have a sour taste and are therefore not preferred by some consumers. Their flavors may need to be improved with sweeteners (Varga, 2006; Sert et al., 2011; Păucean et al., 2011). Various sweeteners can be added yogurt. Today, most yogurts are sweetened using sugar (Aryana \& Olson, 2017). There are also researchers who try to use different sweeteners. Popa \& Ustunol (2011) sweetened yogurts by adding sucrose, high fructose corn syrup and different honeys. In terms of overall acceptance, the most popular yoghurts were yoghurts with sucrose, with high-fructose corn syrup and with sage honey, respectively. Yoghurt with sage honey was more popular than high-fructose corn syrup in terms of sweetness and flavour.

Honey may be a better option than artificial flavorings for use in the development of new dairy products (Machado et al., 2017). Honey due to functional properties can be used as sweetener in yoghurt production (Roumyan et al., 1996; Chick et al., 2001). Honey added yogurt is the perfect food especially for children (Păucean et al., 2011; Garanis-Papadatos \& Katsas, 1999). In this study, pine honey was used as honey. Pine honey is produced by processing of secretion of Marchalina hellenica by honey bees (Tananaki et al., 2007; Akbulut et al., 2009; Silici, 2011). Marchal hellenica lives on Pinus brutia growed only in Turkey and Greece (Santas, 1979) (especially in Southern Marmara, the Aegean and Western Mediterranean region) (Özkök et al., 2010). At a research, the main content of pine honey was determined as average water $16.51 \%$, fructose $35.38 \%$, glucose $27.97 \%$, sucrose $2.91 \%$, fructose/glucose ratio $1.21 \%$, fructose+glucose $62.31 \%$, saccarose $0.64 \%$, maltose $1.32 \%$, total ash $0.45 \%$ (Öğretmen \& İnanan, 2014). The average $\mathrm{pH}$, protein values of pine honey samples were 4.53 and $3.57 \mathrm{mg} / \mathrm{kg}$, respectively. The honey contains ascorbic acid, peptides, enzymes such as glucose oxidase and catalase (Gheldof et al., 2002; Nicholls \& Miraglio, 2003).

Honey has antimutagenic, antibacterial and antioxidant effects (Erejuwa et al., 2010). Honey can act as a preservative and sweetener in dairy products (Varga, 2006; Chick et al., 2001). Therefore, The honey used in the appropriate proportions does not affect the viability of bacteria such as Lb. acidophilus, S. thermophilus, B. bifidum and Lb. delbrueckii (Sanz et al., 2005; Ezz El-Arab et al., 2006; Sert et al., 2011).

In this study, physicochemical, microbiological and sensory properties of pine honey added $(2 \%, 4 \%$ and $6 \% \mathrm{w} / \mathrm{v})$ probiotic yoghurt samples were investigated during refrigerated storage for 3 weeks.

\section{Material and methods}

\subsection{Preparation of starter culture}

Yoghurt starter culture (Bizim Probiotic Yoghurt Culture), a combination of Streptococcus thermophilus, Lactobacillus delbueckii ssp. bulgaricus, Lactobacillus rhamnosus, Lactobacillus acidophilus, Lactobacillus plantarum, Bifidobacterium animals ssp. lactis supplied by the Doğadan Bizim Gıda ve Süt Ürünleri
San. ve Tic. Ltd. Şti. in Istanbul, Turkey. According to the instructions of the firm to produce yoghurt, $2 \mathrm{gr}$ of freeze dried culture should be inoculed into $5 \mathrm{~kg}$ yoghurt milk. Culture was activated by inoculation ( $2 \mathrm{~g}$ freeze dried culture $/ 100 \mathrm{~mL}$ milk) into pasteurised cow's milk (Ülker İçim fresh daily milk) (fat $3.1 \%$ and protein $2.8 \%$ ) produced by Ak Gida San. ve Tic. A.Ş. in Pamukova, Sakarya, Turkey. The milk was inoculated after heating at $43{ }^{\circ} \mathrm{C}$ and incubated at $43^{\circ} \mathrm{C}$ until the $\mathrm{pH}$ reached 4.6 , then were stored overnight at $+4^{\circ} \mathrm{C}$.

\section{Production of yoghurt}

Milk was heated to $43{ }^{\circ} \mathrm{C}$ for yoghurt production. Later, activated culture added into $4900 \mathrm{~mL}$ of milk. Milk without honey and milk with honey $(2 \%, 4 \%, 6 \%)$ samples were prepared from this milk. $100 \mathrm{~mL}$ of milk with honey and without honey were distributed in $150 \mathrm{~mL}$ plastic containers. Fermentation took approximately $6 \mathrm{~h}$ at $43^{\circ} \mathrm{C}$. Yoghurt samples were cooled up to ambient temperature for 30 minutes and then stored at $4{ }^{\circ} \mathrm{C}$ for 12 hours. Analysis were performed at the end of these 12 hours, on days 7, 14 and 21. Experiments were applied out in triplicate. Pine honey (Saklı Cennet Organic Pine Honey) was supplied by Temarı Gıda San. ve Tic. A. Ş. in Muğla, Turkey.

\section{Physicochemical analysis}

The $\mathrm{pH}$ value of milk was measured at room temperature by means of a pH meter (Hanna Instruments P2960-pH211) (Akalın et al., 2012). The nonfat dry matter of milk was determined by subtracting the fat value (\%) from the dry matter value of milk (Turkish Standards Institution, 2006). The density of milk was measured by means of a lactodisimeter at $15{ }^{\circ} \mathrm{C}$ (Demirci \& Gündüz, 1994).

The refractive indice of the honey sample was measured with a refractometer (Zeiss) $\left(\right.$ at $\left.20^{\circ} \mathrm{C}\right)$. The relationship between the refractive index and water content was used for calculating the moisture content (\%). The saccharose and reducing sugar content of pine honey was determined by Lane-Eynon titrimetric method. The $\mathrm{pH}$ of the honey was determined by using the $\mathrm{pH}$ meter after adding $10 \mathrm{~g}$ of honey to $75 \mathrm{~mL}$ of distilled water (Association of Official Analytical Chemists, 1990). Total acidity and free lactone acid were determined using the titrimetric method; $0.05 \mathrm{~N} \mathrm{NaOH}$ was added until the $\mathrm{pH}$ was 8.50 (free acidity). After the addition of $10 \mathrm{~mL}$ of $0.05 \mathrm{~N} \mathrm{NaOH}$, immediately titrated with $0.05 \mathrm{M} \mathrm{HCl}$ until pH 8.30 (lactonic acid). The sum of free acids and lactonic acids gave total acidity (Naman et al., 2005; Adenekan et al., 2010). Results were stated as Milliequivalent of acid for each kilogram of honey. Color of pine honey was measured by spectrophotometer (Minolta CM-3610D) (Nyawali et al., 2015).

The $\mathrm{pH}$ values of yoghurt samples were measured by means of a $\mathrm{pH}$ meter at room temperature (Hanna Instruments P2960-pH211) (Akalın et al., 2012). Yoghurt sample (10 g) was diluted with distilled water $(10 \mathrm{~mL})$. Then mix was titrated by adding $0.1 \mathrm{~N} \mathrm{NaOH}$. Phenolphthalein was used as the indicator. Acidity was calculated as lactic acid in \% by mass (Turkish Standards Institution, 2006). The centrifugation method was used to measure the water holding capacity. The yoghurt sample 
(5 gram) was centrifuged by using a centrifuge $(4500 \mathrm{rpm} / \mathrm{min}$ for $30 \mathrm{~min}$ at $\left.10^{\circ} \mathrm{C}\right)(115 \mathrm{~V}, 50 / 60 \mathrm{~Hz}$ and $1.2 \mathrm{Amp})(\mathrm{Damon} / \mathrm{IEC}$ Division, Needham Hts., Mass.). The pellet weight was recorded after the supernatant was removed. Water holding capacity was calculated as [1-(pellet weight/initial sample weight) $\times 100$ (Wu et al., 2001). The serum separation (syneresis) of yoghurt samples was analyzed during storage (Atamer \& Sezgin, 1986). After twenty-five grams of yoghurt sample was filtered at $4 \pm 1{ }^{\circ} \mathrm{C}$ for 120 minutes, the amount $(\mathrm{mL})$ of the collected whey in a bottle was recorded and stated as a synergistic index. The $\mathrm{L}^{*}, \mathrm{a}^{*}$ and $\mathrm{b}^{*}$ colour values were measured by using a Hunter-Lab D 25 A Optical Sensor on the 7th day of storage (Cueva \& Aryana, 2008).

\section{Microbiological analysis}

To prepare the first dilution, $10 \mathrm{~mL}$ of yoghurt samples was aseptically mixed with $90 \mathrm{~mL}$ of $0.1 \%$ peptone water. Other dilutions were prepared as required. Spread plate method was used to determine the number of living cells. M17 agar (Merck, Germany) was used for the counting of S. thermophilus. Incubation lasted 48 hours at $37{ }^{\circ} \mathrm{C}$ under aerobic conditions. Lenticular colonies of 1 to $2 \mathrm{~mm}$ in diameter were accepted as S. thermophilus (International Diary Federation, 1997). Acidified MRS agar (Oxoid CM 361) to pH 5.2 was used for counting $L b$. delbrueckii ssp. bulgaricus and acidified MRS-Sorbitol Agar to $\mathrm{pH} 5.2$ by using HCL was used for counting Lb. acidophilus. Incubation of the plates lasted 72 hours at $37^{\circ} \mathrm{C}$ under anerobic conditions. (Dave \& Shah, 1996). AnaeroGen AN 25 packages (Oxoid) were used to create anaerobic conditions in anaerobic culture jars with a volume of $2.5 \mathrm{~L}$. Lenticular colonies, usually sharp-shaped and 1 to $3 \mathrm{~mm}$ in diameter, were accepted as $L b$. bulgaricus (International Diary Federation, 1997). The counts were stated as $\log \mathrm{cfu} / \mathrm{g}$.

\section{Sensory analysis}

Sensory properties were analysed by ten panelists on the 7 th day of storage. Samples were presented to panelists in $150 \mathrm{~mL}$ plastic containers used in the production of yoghurt. The appearance (by looking to yoghurt sample in daylight directly), the consistency with the spoon, the consistency in the mouth, the odor and taste characteristics of yoghurt samples were taken into consideration during scoring. The hedonic scale proposed by Rasic \& Kurmann (1978) was used to evaluate of sensory properties of yoghurt samples. Panelists were given scores from 0 to 5 for these features (Rasic \& Kurmann, 1978; Demirkaya \& Gökalp, 2009; Coşkun \& Şenoğlu, 2011).

\section{Experimental design and statistical analysis}

Differences between the samples were statistically tested due to the increase in storage days and the addition of honey at varying rates. During the evaluation of sensory and colour analysis results, the difference between the groups was determined using one-way anova analysis. During the evaluation of phsicochemical and microbiological analysis results, the difference between the groups was determined using the univeriate general linear model procedure of the SPSS statistical software programme (version 18; SPSS, Inc., Chicago, IL, USA). Duncan's multiple comparison test was used to determine significant differences among the means at $\mathrm{P}<0.01$ (Düzgüneş et al., 1978). All analyses and measurements were repeated in triplicates.

\section{Results and discussion}

Organoleptic, rheological, texture, microstructure and nutritional composition properties of yogurt depend on several factors such as fermentation process, type of milk (whole, semi or skimmed milk), species of milk obtained (i.e., cow, goat, sheep, buffalo, ewe, camel, yak, non-dairy milk), types of milk solids, solid non-fat, starter cultures and probiotic strains, packaging and storage conditions, components added such as sweeteners and flavour (Fazilah et al., 2018; Weerathilake et al., 2014).

Physicochemical properties of the milk used for yoghurt production in this research were as follows: $\mathrm{pH}$, fat (\%), non fat dry matter $(\%)$, density $(\mathrm{g} / \mathrm{mL})$, protein $(\%)$ were $6.98,3.1$, $10.83,1.028$ and 2.8, respectively. Physicochemical properties of the pine honey were as follows: $\mathrm{pH}$, acidity (meq/kg), brix (\%), invert sugar $(\mathrm{g} / \mathrm{kg})$, saccharose $(\mathrm{g} / \mathrm{kg})$, total sugar $(\mathrm{g} / \mathrm{kg})$ were $4.81,22,26,521.47,121.28$ and 642.95 , respectively. Color values $\left(\mathrm{L}^{*}, \mathrm{a}^{*}, \mathrm{~b}^{*}\right)$ were $56.56,27.12$ and 88.40 , respectively. The effect of honey adding on the $\mathrm{pH}$ of the yogurt milk was followed during the fermentation process (Table 1). The $\mathrm{pH}$ values of all yoghurt samples decreased to 4.65-4.58 after 6 hours of incubation. Fermentation of honey added yoghurt samples were completed earlier than control yoghurt. Since probiotic bacteria growth slowly in milk, it is necessary to add yogurt starter cultures to shorten the fermentation time (Shah \& Lankaputhra, 1997). Probiotic bacteria may adversely affect the development of other starter bacteria through the metabolites they produce during fermentation and extend the fermentation process. In particular, Acidophiline LA-1, a bacteriocin synthesized by Lb. acidophilus inhibits the growth of $L b$. delbrueckii ssp. bulgaricus. In contrast, hydrogen peroxide produced by $L b$. delbrueckii ssp. bulgaricus slows down the development of Lb. acidophilus (Özer, 2010).

In the study which is conducted by Varga (2006), the $\mathrm{pH}$ of milk with acacia honey $(1 \%, 3 \%$ and $5 \% \mathrm{w} / \mathrm{v})$ at different ratios dropped over the $6 \mathrm{~h}$ of incubation. There was no significant difference between the $\mathrm{pH}$ values of yoghurt samples with honey at different ratios $(\mathrm{P}>0.05)$. Glušac et al. (2015) determined that fermentation of honey ( $2 \%$ and $4 \%)$ and whey protein enriched yoghurt samples were completed earlier than the control sample.

Table 1. $\mathrm{pH}$ values of the yoghurt milk during the fermentation.

\begin{tabular}{ccccc}
\hline Fermentation time $(\mathrm{h})$ & Control & A1 & A2 & A3 \\
\hline At the beginning of fermentation & 6.98 & 6.96 & 6.90 & 6.82 \\
1 & 6.86 & 6.88 & 6.83 & 6.74 \\
2 & 6.73 & 6.80 & 6.77 & 6.71 \\
3 & 6.68 & 6.68 & 6.60 & 6.58 \\
4 & 6.64 & 6.63 & 6.52 & 6.39 \\
5 & 5.60 & 5.49 & 5.37 & 5.26 \\
6 & 4.65 & 4.60 & 4.62 & 4.58 \\
\hline
\end{tabular}

Control: Yoghurt sample without pine honey; A1: Yoghurt sample with pine honey (2\%); A2: Yoghurt sample with pine honey (4\%); A3: Yoghurt sample with pine honey (6\%). 
$\mathrm{pH}$, acidity (\%), water holding capacity (g/5g), serum seperation (\%) values of yoghurt samples during storage were shown in Table 2. The $\mathrm{pH}$ values decreased during storage (21 days) at $4{ }^{\circ} \mathrm{C}$. The $\mathrm{pH}$ value of the control group decreased 0.25 units during the 21 day storage period. The $\mathrm{pH}$ values of honey added yoghurt samples $(2 \%, 0.29$ unit; $4 \%, 0.27$ unit; except $6 \%, 0.23$ unit) decreased higher than control group. In the analysis of variance performed, the differences among the yoghurt samples and storage days were found to be significant at the level of $\mathrm{P}<0.01$. According to the Duncan test to determine the level of difference among the yoghurt samples, all honey added yoghurt samples were similar to each other and different from the control sample. According to the Duncan test to determine the level of the differences among the storage days, all the samples were found to be different from each other.

The $\mathrm{pH}$ of the honey added yogurt samples was lower than the honey free yogurt sample during storage. These changes in $\mathrm{pH}$ values observed in yogurt formulations containing pine honey could be related to the presence of extra fermentable compounds as glucose and fructose pine honey. However, the decrease in $\mathrm{pH}$ decreased with the increase in the rate of honey during storage. In addition, the increase in acidity decreased with the increase in the rate of honey. This may be due to the high rate of honey adversely affecting the microorganism activity. This situation can be related to the kind of honey and its contents. In the study of Machado et al. (2017), the $\mathrm{pH}$ of the honey added samples was lower than the sample without honey and decreased during storage.

Sert et al. (2011) determined the effect to yoghurt milk of sunflower honey addition $(2 \%, 4 \%$ and $6 \% \mathrm{w} / \mathrm{v})$. The $\mathrm{pH}$ values of all the samples decreased to 4.6-4.7 at the end of 3.5 hours of incubation. The $\mathrm{pH}$ values of yoghurt samples with honey at different ratios were higher than those without honey. The $\mathrm{pH}$ value increased as the honey ratio increased in yoghurt. On the contrary, in this study, the $\mathrm{pH}$ values of the honey added samples were found to be slightly lower than those of the honey free sample. In this study, $\mathrm{pH}$ values at the end of fermentation are similar to $\mathrm{pH}$ values in their work. In this study, fermentation lasted longer than their study. This may be due to the number or variety of microorganisms in the inoculated culture.

Glušac et al. (2015) found that the $\mathrm{pH}$ values of yoghurt samples with acacia honey added at different ratios at beginning and end of storage (21 days) were lower according to the ones without honey. The results of this study are similar to those of Glusac et al. At a research conducted by Ammar El-Tahra et al. (2015), the $\mathrm{pH}$ values of yoghurt samples containing honey and ABT culture (S. thermophilus, Lb. acidophilus, B. bifidum) were lower than the $\mathrm{pH}$ values of samples containing only ABT culture at the beginning and at the end of storage (15 day) as it is in this study. The reason for this may be a prebiotic effect of honey.

The lowest acidity level on the 1st day of storage was $0.630 \%$ in the control group while the highest acidity was determined as $0.787 \%$ in $6 \%$ honey added yoghurt sample. After 21 days, the acidity $(0.882 \%)$ of the sample containing $2 \%$ honey is higher than the others. The maximum increase in acidity was observed in $2 \%$ honey added yoghurt sample during the storage period. In the analysis of variance performed, the differences among the yoghurt samples and storage days was found to be significant at the level of $\mathrm{P}<0.01$. According to the Duncan test to determine the level of difference among the yoghurt samples, only $2 \%$ and $6 \%$ honey added yoghurt samples were similar to each other. According to the Duncan test to determine the level of the differences among the storage days, all the samples were found to be different from each other.

In Ammar's study (Ammar El-Tahra et al., 2015) the acidity of yoghurt samples with acacia honey at the start and end of storage (15 days) were higher according to the ones

Table 2. The phsicochemical properties of the yoghurt samples during the storage.

\begin{tabular}{|c|c|c|c|c|c|}
\hline Treatments & $\begin{array}{l}\text { Storage Periods } \\
\text { (days) }\end{array}$ & $\mathrm{pH}$ & $\begin{array}{c}\text { Acidity } \\
(\%)\end{array}$ & $\begin{array}{l}\text { Water Holding } \\
\text { Capacity }(\mathrm{g} / 5 \mathrm{~g})\end{array}$ & $\begin{array}{c}\text { Serum Seperation } \\
(\%)\end{array}$ \\
\hline \multirow{2}{*}{ Control } & 7 & $4.56^{\mathrm{aB}}$ & $0.729^{\mathrm{aB}}$ & $2.30^{\mathrm{aB}}$ & $51.52^{\mathrm{aB}}$ \\
\hline & 21 & $4.34^{\mathrm{aD}}$ & $0.810^{\mathrm{aD}}$ & $1.98^{\mathrm{aD}}$ & $38.36^{\mathrm{aD}}$ \\
\hline \multirow[t]{2}{*}{$\mathrm{A} 1$} & 0 & $4.48^{\mathrm{bA}}$ & $0.720^{\mathrm{bA}}$ & $2.68^{\mathrm{bA}}$ & $49.00^{\mathrm{bA}}$ \\
\hline & 21 & $4.19^{\mathrm{bD}}$ & $0.882^{\mathrm{bD}}$ & $2.30^{\mathrm{bD}}$ & $35.84^{\mathrm{bD}}$ \\
\hline \multirow[t]{4}{*}{ A2 } & 0 & $4.48^{\mathrm{bA}}$ & $0.765^{\mathrm{cA}}$ & $2.69^{\mathrm{cA}}$ & $48.64^{\mathrm{cA}}$ \\
\hline & 7 & $4.37^{\mathrm{bB}}$ & $0.772^{\mathrm{cB}}$ & $2.65^{\mathrm{cB}}$ & $48.20^{\mathrm{CB}}$ \\
\hline & 14 & $4.27^{\mathrm{bC}}$ & $0.783^{\mathrm{cC}}$ & $2.51^{\mathrm{cC}}$ & $40.56^{\mathrm{cC}}$ \\
\hline & 21 & $4.21^{\mathrm{bD}}$ & $0.819^{\mathrm{cD}}$ & $2.44^{\mathrm{cD}}$ & $38.88^{\mathrm{cD}}$ \\
\hline
\end{tabular}

\footnotetext{
Control: Yoghurt sample without pine honey; A1: Yoghurt sample with pine honey (2\%); A2: Yoghurt sample with pine honey (4\%); A3: Yoghurt sample with pine honey (6\%). ${ }^{\star}$ Mean
} in the same colums with different small letters are significantly different $(\mathrm{P}<0.01)$ (difference among yoghurt samples); ${ }^{* \star}$ Mean in the same colums with different capital letters are significantly different $(\mathrm{P}<0.01)$ (difference among storage days). 
without honey. The results of this study are similar to those of Ammar El-Tahra et al. (2015) produced bio-yoghurt with honey $(2 \%, 4 \%$ and $6 \% \mathrm{w} / \mathrm{v})$ and at the end of the fermentation, the addition of honey did not have a significant effect on the acidity of the yoghurt samples.

The highest serum separation (syneresis) level on the 1st day of storage was $52.68 \%$ in the control group while the lowest serum seperation was determined as $48.60 \%$ in $6 \%$ honey added yoghurt sample. After 21 days, the highest serum seperation level was $40 \%$ in $6 \%$ honey added yoghurt sample while the lowest serum seperation was determined as $35.84 \%$ in $2 \%$ honey added yoghurt sample. As statistical, the differences among the yoghurt samples and storage days were found to be significant at the level of $\mathrm{P}<0.01$. According to the Duncan test to determine the level of difference among the yoghurt samples, only $4 \%$ and $6 \%$ honey added yoghurt samples were similar to each other. According to the Duncan test to determine the level of the differences among the storage days, all the samples were found to be different from each other.

In Çelik et al.s works (Çelik et al., 2009), serum separation values of set type yoghurt samples with juniper molasses decreased until the 14th day of storage, increased in the following days. In this study, the rate of serum separation increased with increasing honey ratio after the 14th day of storage. In the study conducted by Machado et al. (2017), serum separation in goat's yoghurt with $5 \%$ stingless bee honey was less than in the yogurt without honey as in this study. In their study, serum separation rates are higher than in this study. This may be due to differences in fermentation conditions, milk source, honey and microorganisms used. Microbial activity in yogurt continues during storage. The acidity increases with proteins and lactose degradation. The water holding capacity of proteins increases with increasing acidity. Thus, serum separation is reduce and yogurt stability increase (Tosun, 2007; Çelik et al., 2009). Besides, decrease of serum seperation may be associated with high osmolarity of honey as an ingredient in the prepared yogurt, which would attract water to the yogurt-forming casein micelles, reducing the water release to the surroundings (Machado et al., 2017). The honey is a high viscosity fluid, but when maintained under refrigeration temperature it behaves like a pseud-plastic fluid, offering better resistance to yoğurt (Pereira, 2003; Machado et al., 2017).

On the 1st day of storage, the lowest water holding capacity value was $2.24 \mathrm{~g} / 5 \mathrm{~g}$ in the control sample while the highest water holding capacity value was $2.69 \mathrm{~g} / 5 \mathrm{~g}$ in $4 \%$ honey added yoghurt sample. The water holding capacity decreased in all samples during storage. At the 21th day of storage, the water holding capacity was lower when compared to the first day of storage for all yogurt formulations, and water holding capacity was lower in the yogurt without added honey. The differences among the yoghurt samples and storage days were found to be significant at the level of $\mathrm{P}<0.01$. According to the Duncan test to determine the level of difference among the variables, all yoghurt samples were different from each other. In a study in which set type yoghurt samples with sunflower honey were investigated, water holding capacity decreased during storage in control sample. In yoghurt samples with sunflower honey, water holding capacity increased during storage. The values increased with increasing honey ratio (Sert et al., 2011). It was thought that the difference between these two studies can be caused by differences of microorganism content in starter cultures, the production method and compound of milk and honey was used in yoghurt production.

The color values determined on the 7 th day of storage of the yoghurt samples were shown in Table 3. The highest brightnes value was determined in the sample with $2 \%$ honey. The brightness decreased with honey ratio increase. The $\mathrm{a}^{*}$ and $\mathrm{b}^{\star}$ values of all samples with honey were higher than control sample. In terms of $L^{*}$ and $b^{*}$ values, the difference among yoghurt samples was statistically significant $(\mathrm{P}<0.01)$. In terms of $\mathrm{L}^{*}$ values, according to the Duncan test to determine the level of difference among the yoghurt samples, control sample, $2 \%$ honey addition sample and $6 \%$ honey addition sample are different from each other. The $4 \%$ honey addition sample is similar to the other honey addition samples. In terms of $b^{\star}$ values, all yoghurt samples were different from each. The difference among $\mathrm{a}^{*}$ values was insignificant $(\mathrm{P}>0.01)$. In Sert's works (Sert et al., 2011), on the 7 th day of storage, $L^{*}$ values decreased with the increase of honey ratio as in this work. Color plays an important role in predicting the quality of the product before consumer tastes the product (Sert et al., 2011). In the study of Machado et al. (2017), the $\mathrm{a}^{*}$ and $\mathrm{b}^{*}$ values increased with the increase in the rate of added honey in 7 days of storage as in this study.

The microbiological properties of the yoghurt samples during the storage were shown in Table 4. Lb. delbrueckii ssp. bulgaricus counts from the beginning to the end of storage were lower than control samples in yoghurt with honey samples. $L b$. delbrueckii ssp. bulgaricus counts decreased control sample and $6 \%$ honey added yoghurt sample during storage while decreased 2 and $4 \%$ honey added yoghurt sample until the 7 th day and later increased. In terms of yoghurt types and storage days, differences among samples were significant $(\mathrm{P}<0.01)$. According to the Duncan test to determine the level of difference among the yoghurt samples, only $2 \%$ and $4 \%$ honey added yoghurt samples were similar to each other. According to the Duncan

Table 3. Color values of yoghurt samples.

\begin{tabular}{ccccc}
\hline Samples & Yellowness Index & $\mathrm{L}^{*}$ & $\mathrm{a}^{*}$ & $\mathrm{~b}^{*}$ \\
\hline Control & 10.26 & $104.48 \mathrm{a}$ & $-2.55 \mathrm{a}$ & $7.50 \mathrm{a}$ \\
$\mathrm{A} 1$ & 10.26 & $109.83 \mathrm{~b}$ & $-1.39 \mathrm{a}$ & $8.90 \mathrm{~b}$ \\
$\mathrm{~A} 2$ & 12.87 & $109.37 \mathrm{bc}$ & $-1.53 \mathrm{a}$ & $9.85 \mathrm{c}$ \\
$\mathrm{A} 3$ & 13.33 & $107.81 \mathrm{c}$ & $-1.37 \mathrm{a}$ & $10.86 \mathrm{~d}$ \\
\hline
\end{tabular}

Control: Yoghurt sample without pine honey; A1: Yoghurt sample with pine honey (2\%); A2: Yoghurt sample with pine honey (4\%); A3: Yoghurt sample with pine honey (6\%). Mean in the same colums with different small letters are significantly different $(\mathrm{P}<0.01)$ (difference among yoghurt samples). 
Table 4. The microbiological properties of the yoghurt samples during the storage (log cfu/g).

\begin{tabular}{|c|c|c|c|c|}
\hline Treatments & Storage Periods (days) & $\begin{array}{l}\text { Lb. delbrueckii ssp. } \\
\text { bulgaricus }\end{array}$ & Lb. acidophilus & S. thermophilus \\
\hline \multirow[t]{4}{*}{ Control } & 0 & $7.95^{a \star A \star *}$ & $7.70^{\mathrm{aA}}$ & $7.87^{\mathrm{aA}}$ \\
\hline & 7 & $7.84^{\mathrm{aB}}$ & $7.62^{\mathrm{aB}}$ & $8.11^{\mathrm{aA}}$ \\
\hline & 14 & $7.60^{\mathrm{aC}}$ & $7.51^{\mathrm{aC}}$ & $7.90^{\mathrm{aA}}$ \\
\hline & 21 & $7.60^{\mathrm{aC}}$ & $7.53^{\mathrm{aBC}}$ & $8.07^{\mathrm{aA}}$ \\
\hline \multirow[t]{4}{*}{$\mathrm{A} 1$} & 0 & $6.84^{\mathrm{bA}}$ & $7.00^{\mathrm{bA}}$ & $8.00^{\mathrm{aA}}$ \\
\hline & 7 & $6.17^{\mathrm{bB}}$ & $6.07^{\mathrm{bB}}$ & $8.17^{\mathrm{aA}}$ \\
\hline & 14 & $6.47^{\mathrm{bC}}$ & $6.65^{\mathrm{bC}}$ & $8.20^{\mathrm{aA}}$ \\
\hline & 21 & $6.69^{\mathrm{bC}}$ & $6.30^{\mathrm{bBC}}$ & $8.77^{\mathrm{aA}}$ \\
\hline \multirow[t]{4}{*}{$\mathrm{A} 2$} & 0 & $6.90^{\mathrm{bA}}$ & $7.04^{\mathrm{bA}}$ & $8.32^{\mathrm{aA}}$ \\
\hline & 7 & $6.00^{\mathrm{bB}}$ & $6.17^{\mathrm{bB}}$ & $8.20^{\mathrm{aA}}$ \\
\hline & 14 & $6.30^{\mathrm{bC}}$ & $6.46^{\mathrm{bC}}$ & $8.00^{\mathrm{aA}}$ \\
\hline & 21 & $6.54^{\mathrm{bC}}$ & $6.77^{\mathrm{bBC}}$ & $8.54^{\mathrm{aA}}$ \\
\hline \multirow[t]{4}{*}{$\mathrm{A} 3$} & 0 & $6.95^{\mathrm{cA}}$ & $7.00^{\mathrm{bA}}$ & $8.47^{\mathrm{aA}}$ \\
\hline & 7 & $6.90^{\mathrm{cB}}$ & $6.60^{\mathrm{bB}}$ & $8.38^{\mathrm{aA}}$ \\
\hline & 14 & $6.97^{\mathrm{cC}}$ & $6.23^{\mathrm{bC}}$ & $8.07^{\mathrm{aA}}$ \\
\hline & 21 & $6.81^{\mathrm{cC}}$ & $6.60^{\mathrm{bBC}}$ & $8.60^{\mathrm{aA}}$ \\
\hline
\end{tabular}

test to determine the level of difference among the storage days, only $4 \%$ and $6 \%$ honey added yoghurt samples were similar to each other. Metry Wedad \& Oways (2009) determined that $L b$. bulgaricus count in yoghurt sample with $4 \%$ honey decreased from the beginning to the 9th day of storage. Roumyan et al. (1996) investigated the effect of acacia honey and polyfloral honey on the vitality of yoghurt starter cultures. Honeys showed significant inhibitory effect on Lb. bulgaricus. Similar results were found in this study. In study conducted by Saccaro et al. (2009), in yoghurt sample added Lb. acidophilus ve B. animalis ssp. lactis with yoghurt starters, $L b$. delbrueckii ssp. bulgaricus count decreased from $7.25 \log 10 \mathrm{cfu} / \mathrm{ml}$ to $6.15 \log 10 \mathrm{cfu} / \mathrm{ml}$ during 21 days storage at $4^{\circ} \mathrm{C}$.

S. thermophilus counts of yoghurt samples did not change much during storage and from the beginning they were higher than control samples in yoghurt with honey samples. The effect of adding honey and storage to $S$. thermophilus counts had been found to be insignificant as statistical. In Sert's study (Sert et al., 2011), viability rate (\%) of S. thermophilus increased in $2 \%$ and $4 \%$ honey added yoghurt samples on the 21 st and 28 th days of storage. At a research conducted by Varga (2006), the addition of acacia honey ( $1 \%$ and $5 \%$ ) to yoghurt milks did not significantly affect the growth and survival of Streptococci during the production and storage of yoghurt $(\mathrm{P}>0.05)$. S. thermophilus was detected in high numbers at the beginning of storage and at the end of storage for 6 weeks. Counts of Streptococci were between 8.28 and $8.81 \log \mathrm{cfu} / \mathrm{mL}$ during storage. The results of this study are similar to those of Varga \& Sert et al. Saccaro et al. (2009) observed that the $S$ thermophilus count decreased from $8.92 \log _{10} \mathrm{cfu} / \mathrm{ml}$ to $8.82 \log _{10} \mathrm{cfu} / \mathrm{mL}$ by not showing any significant change during 21 days of storage. It has been determined that $S$. thermophilus can better tolerate sugar than Lb. bulgaricus (Üçüncü, 2005). S. thermophilus prepares anaerobic conditions due to its oxygen consumption and promotes the growth of bacteria that can develop under these conditions (Özer, 2006).
During the storage period, the number of Lb. acidophilus was lower in yoghurt samples with honey compared to the control sample. Nevertheless, the numbers of probiotic bacteria in all yogurt samples were suitable for human consumption throughout storage period. The effect of adding honey and storage to Lb. acidophilus counts had been found to be significant $(\mathrm{P}<0.01)$. According to the Duncan test to determine the level of difference among the yoghurt samples, all honey added yoghurt samples were similar to each other and different from the control sample. According to the Duncan test to determine the level of difference among the storage days, all yoghurt samples other than $6 \%$ honey yogurt samples were different from each other, but the $6 \%$ honey addition sample was similar to other honey added samples.

In study of Saccaro et al. (2009), while $L b$. acidophilus count was $7.17 \log _{10} \mathrm{cfu} / \mathrm{mL}$, at 1 st day of storage, it decreased to $5.26 \log _{10} \mathrm{cfu} / \mathrm{ml}$ at the 14 th day of storage, that number has fallen below $5 \log _{10} \mathrm{cfu} / \mathrm{mL}$ at 21 st day of storage. The viability of probiotic bacteria in fermented milk is decreased due to the damage caused by the acid formed (Shah, 2000). If the acid content of the medium is slightly increased as a result of honey addition, low acid tolerance probiotic bacteria are adversely affected (Ammar El-Tahra et al., 2015). At the end of incubation, acidity should be above $\mathrm{pH} 4.6$ and rapid cooling should be performed to prevent acidity (Özer, 2010). Hydrogen peroxide produced by $L b$. delbrueckii ssp. bulgaricus was responsible for the loss in viability of $L b$. acidophilus when added in yogurt (Kailasapathy \& Rybka, 1997). The viability of microorganisms also depends on nutrients, growth and inhibition factors in the medium, the fermentation period, storage temperature (Dave \& Shah, 1996; Shah et al., 2000). Starter culture and probiotic bacteria can produce exopolysaccharide. High exopolysaccharides may provide a better texture for yogurt (Han et al., 2016). It is known that microbial exopolysaccharides may improve body and texture of fermented products as they serve as emulsifying 
or gelling agents, thickening and stabilising agents (Aryana et al., 2007; Fazilah et al., 2018).

Sensory analysis of yoghurt samples was performed by 11 people on the 7 th day of storage. The characteristics of yoghurt were evaluated with scores between 1 and 5 . The sensory scores were obtained by applying appearance, consistency on spoon, consistency in mouth, odor and taste tests were shown Figure 1. $2 \%$ honey added sample was most favored in terms of odor and consistency on spoon, while $4 \%$ honey added sample was most liked for taste. In terms of appearance and consistency in mouth, $2 \%$ and $4 \%$ honey addition samples were equally appreciated. The most popular samples were yoghurt samples with honey $2 \%, 4 \%$ and $6 \%$, respectively. Control sample falled behind these samples.

In general, it has been observed high counts of viable strains as $L b$. acidophilus and B. longum cause slight changes in some physicochemical, and sensory parameters of yogurts along the refrigerated storage (Cruz et al., 2013).

Sensory analysis had been carried out by adults. Adults may be tempted to choose less sweet instead of sweetness. Yoghurts with $4 \%$ and $6 \%$ honey may be more appreciated by children. Because they felt very sugared, the panelists stated that they did not like $6 \%$ honey yogurt. Fruit yogurt is a sweeter yogurt type than plain yogurt. According to the results of a study conducted in Ordu Province of Turkey. $30.7 \%$ of all participants over 15 years old (most of the participants are aged 36-49) love fruit yogurt. $69.3 \%$ of them do not like fruit yoğurt (Tarakçı et al., 2015). In another study, sweet preferences and sugar consumption of 4-5 year-old children researched. In this study, sweetened yogurt is included in the favorite food group of children. Families who say" Children just like sweet foods, and there is nothing you can do about it" are in majority (Liem et al., 2004). Demir et al. (2018) investigated the consumption of milk and products in children aged 10-15 years. In that study, most of the children (46.2\%) stated that they did not like milk because of their taste.
$57.3 \%$ of children consume milk as sweetened with sugar or aroma. Children who rarely consume plain yogurt prefer fruit yogurt compared to plain yogurt while children who consume yogurt daily prefer plain yogurt rather than fruit yoghurt. Therefore, one way of loving yogurt is to add sweetener to it. For this purpose, the use of honey is one of the healthiest ways. In the analysis of variance performed, the difference among the yoghurt samples was found to be significant at the level of $\mathrm{P}<0.01$ only in terms of consistency on spoon. According to the Duncan test to determine the level of difference among the yoghurt samples, control sample and $2 \%$ honey addition sample are different from each other. But, $4 \%$ honey addition sample and $\% 6$ honey addition sample are similar to those samples. Differences in terms of other criteries were insignificant.

Varga (2006) recommended enrichment by honey of yoghurt as sensory properties. In his study, $1 \%$ honey added yoghurt samle was weak in flavor. On the contrary, the flavor of yogurt sample with $5 \%$ honey was very strong and yoghurt was very sweet. The honey added at the concentration of $3.0 \%$ improves the sensory properties of the yogurt without the inhibitor effect on the starter bacteria. In this study, the taste, consistency on mouth and appearance of yoghurt improved with the increase of the honey content added $(0 \%, 2 \%, 4 \%)$ in the yoghurt on the 7 th day of storage while the odor score of yoghurt increased to $2 \%$ honey ratio, and decreased at higher honey rates.

In study conducted by Sert et al. (2011), the taste intensity, consistency and appearance of set-type yoghurt improved with the increase of the honey content added $(0 \%, 2 \%, 4 \%$ and $6 \%)$ in the yoghurt on the 7th day of storage while the odor score of yoghurt reduced. Two studies are similar except $6 \%$ honey added yoghurt. Ammar El-Tahra et al. (2015) determined that bio-yoghurt samples with $4 \%, \% 6$ and $\% 2$ honey respectively have the highest scores in terms of overall acceptability on the 7 th day of storage. In Metry \& Oways's study (Metry Wedad \& Oways, 2009) oweral acceptability of classic yoghurts containing

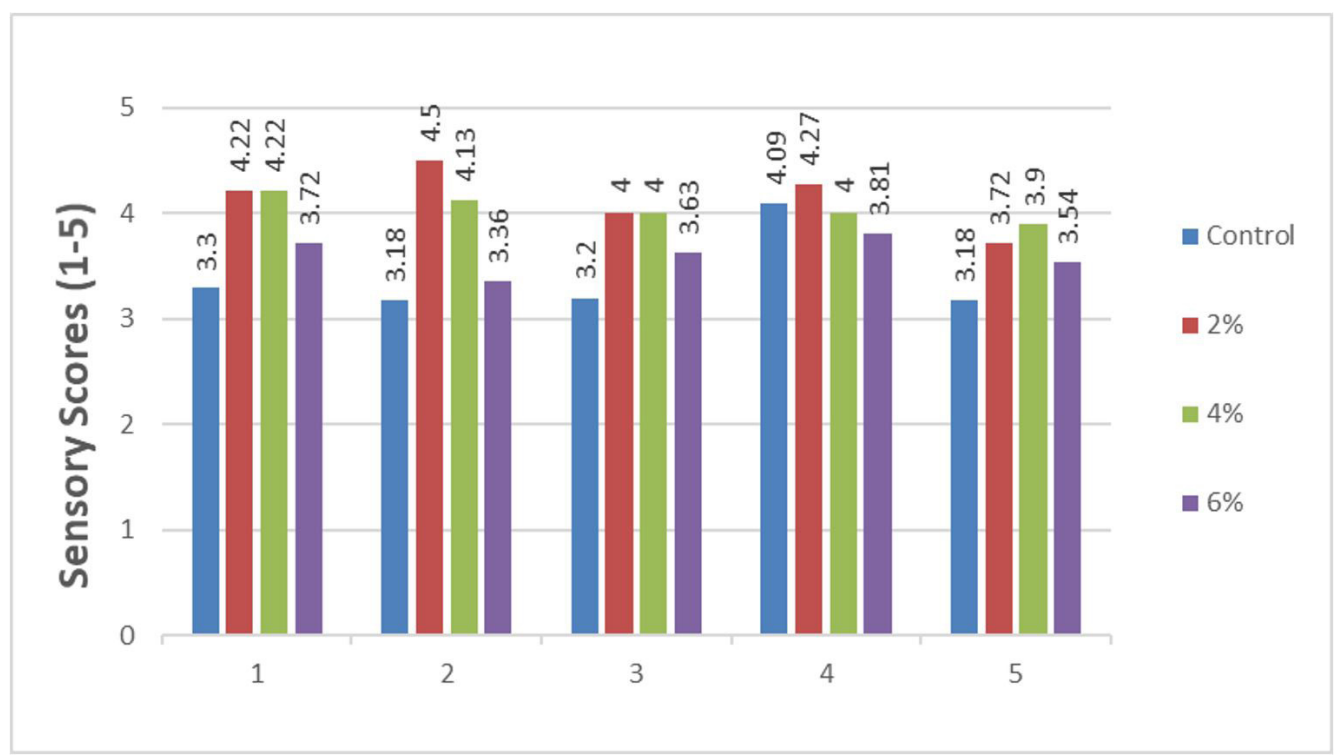

Figure 1. Score graph of sensory properties of yoghurt samples. 1: Appearance, 2: Consistency on spoon, 3: Consistency on mouth, 4: Odor, 5: Taste. 
$2 \%, 4 \% 6 \%$ and $9 \%$ honey was determined. Yoghurt containing $6 \%$ honey have the highest score. Yoghurt samples containing $4 \%, 2 \%$ and $9 \%$ honey followed its. Very high honey ratio gave a negative result.

For more effective sensory analysis, different sensory testing techniques are available. The sensory test (appearance, aroma, taste, texture, and overall impression) can be performed using a 9-point hybrid hedonic scale ( 1 = extremely unloved and 9 = highly loved) (Belsito et al., 2017; Dantas et al., 2016). It should be used advanced testing techniques such as quantitative descriptive analysis (QDA) to determine the formulations of products sensitively optimized and with high-potential success in consumer marketing. Sensory tests should be carried out by a large number of panelists, and panellists should be trained (Janiaski et al., 2016). In order to achieve successful formulations, it can be conducted CATA (Check-all-that-apply) surveys allow to focus on consumers, more representative of the market as well as tests conducted by trained panelist (Torres et al., 2017; Oliveira et al., 2017). Techniques using direct analysis of the terms generated by consumers are considered easy to perform, without specific training requirements, thus improving knowledge about consumer perceptions on various products. It can be used the "comment analysis" and "pivot profile" methods, based on consumers' perceptions (Fonseca et al., 2016).

\section{Conclusion}

Yoghurt is a food that plays an important role from the perspective of health. Probiotic yoghurt is a functional product that has positive effects on the digestive system. According to the results of this research, adding pine honey has significantly affected physicochemical, microbiological and sensory properties of yoghurt. Structural properties of yoghurt improved with the increase of honey. The numbers of $L$ b. delbrueckii ssp. bulgaricus and $L b$. acidophilus were less, the number of $S$. thermophilus was more in pine honey added yoghurt samples than the control sample, from the 1 st to the 21 st day of storage. The numbers of Lb. delbrueckii ssp. bulgaricus and Lb. acidophilus was above the recommended minimum number $\left(\geq 10^{6} \mathrm{cfu} / \mathrm{g}\right)$. Although yoghurt with $2 \%$ pine honey added had the same points as the yoghurt with $4 \%$ pine honey in terms of some sensory properties, it was the most liked yoghurt. Probiotic yogurt consumption is very important for public health. The consumption of probiotic yogurt in childhood will contribute to the growth of more healthy generations. Probiotic yoghurt with pine honey may be a good alternative as a functional product. When the consumer group is target77ed as children, the honey ratio can be increased.

\section{References}

Adenekan, M. O., Amusa, N. A., Lawal, A. O., \& Okpeze, V. E. (2010). Physico-chemical and microbiological properties of honey samples obtained from Ibadan. Journal of Microbiology and Antimicrobials, 2(8), 100-104.

Akalın, A. S., Unal, G., Dinkci, N., \& Hayaloglu, A. A. (2012). Microstructural, textural, and sensory characteristics of probiotic yogurts fortified with sodium calcium caseinate or whey protein concentrate. Journal of Dairy Science, 95(7), 3617-3628. http://dx.doi.org/10.3168/jds.20115297. PMid:22720919.
Akan, E., \& Kınık, Ö. (2015). Factors effecting probiotic viability during processing and storage of food. Celal Bayar University Journal of Science, 11(2), 155-166.

Akbulut, M., Ozcan, M. M., \& Coklar, H. (2009). Evaluation of antioxidant activity, phenolic, mineral contents and some physicochemical properties of several pine honeys collected from Western Anatolia. International Journal of Food Sciences and Nutrition, 60(7), 577-589. http://dx.doi.org/10.3109/09637480801892486. PMid:19817637.

Almeida, K. E., Tamime, A. Y., \& Oliveria, M. N. (2008). Acidification rates of probiotic bacteria in Minas frescal cheese whey. LebensmittelWissenschaft + Technologie, 41(2), 311-316. http://dx.doi.org/10.1016/j. lwt.2007.02.021.

Ammar El-Tahra, M. A., Ismail Magdy, M., Khalil Abd El-Wahab, E., \& Eid Mohamed, Z. (2015). Impact of fortification with honey on some properties of bio-yoghurt. Journal of Microbiology, Biotechnology and Food Sciences, 4(6), 503-508. http://dx.doi.org/10.15414/ jmbfs.2015.4.6.503-508.

Arena, M. P., Caggianiello, G., Russo, P., Albenzio, M., Massa, S., Fiocco, D., Capozzi, V., \& Spano, G. (2015). Functional starters for functional yoğurt. Foods, 4(1), 15-33. http://dx.doi.org/10.3390/foods4010015. PMid:28231187.

Aryana, K. J., \& Olson, D. W. (2017). A 100-Year Review: Yogurt and other cultured dairy products. Journal of Dairy Science, 100(12), 998710013. http://dx.doi.org/10.3168/jds.2017-12981. PMid:29153184.

Aryana, K. J., Plauche, S., Rao, R. M., Mcgrew, P., \& Shah, N. P. (2007). Fat-free plain yogurt manufactured with inulins of various chain lengths and Lactobacillus acidophilus. Journal of Food Science, 72(3), M79-M84. http://dx.doi.org/10.1111/j.1750-3841.2007.00302.x. PMid:17995804.

Association of Official Analytical Chemists - AOAC. (1990). Food composition, additives and natural contaminants. In: K. Helrich (Ed.), Official Methods of Analysis (15th ed.). Arlington: Association of Analytical Chemist International.

Atamer, M., \& Sezgin, E. (1986). Effect of increasing the level of total solids on physical properties of yoghurt. Gida, 11(6), 327-331.

Batista, A. L. D., Silva, R., Cappato, L. P., Almada, C. N., Garcia, R. K. A., Silva, M. C., Raices, R. S. L., Arellano, D. B., Sant'Ana, A. S., Conte Junior, C. A., Freitas, M. Q., \& Cruz, A. G. (2015). Quality. parameters of probiotic yogurt added to glucose oxidase compared to commercial products through microbiological, physical-chemical and metabolic activity analyses. Food Research International, 77(3), 627-635. http:// dx.doi.org/10.1016/j.foodres.2015.08.017.

Belsito, P. C., Ferreira, M. V. S., Cappato, L. P., Cavalcanti, R. N., Vidal, V. A. S., Pimentel, T. C., Esmerino, E. A., Balthazar, C. F., Neto, R. P. C., Tavares, M. I. B., Zacarchenco, P. B., Freitas, M. Q., Silva, M. C., Raices, R. S. L., Pastore, G. M., Pollonio, M. A. R., \& Cruz, A. G. (2017). Manufacture of Requeijão cremoso processed cheese with galactooligosaccharide. Carbohydrate Polymers, 174, 869-875. http:// dx.doi.org/10.1016/j.carbpol.2017.07.021. PMid:28821142.

Casarotti, S. N., Monteiro, D. A., Moretti, M. M. S., \& Penna, A. L. B. (2014). Influence of the combination of probiotic cultures during fermentation and storage of fermented milk. Food Research International, 59, 67-75. http://dx.doi.org/10.1016/j.foodres.2014.01.068.

Çelik, Ş., Durmaz, H., Şat, İ. G., \& Şenocak, G. (2009). Physicochemical and microbiological properties of set type fruit yogurt with juniper molasses. Gida, 34(4), 213-218.

Chen, C., Zhao, S., Hao, G., Yu, H., Tian, H., \& Zhao, G. (2017). Roleoflacticacid bacteria on the yogurt flavour: A review. International Journal of Food Properties, 20(S1), S316-S330. http://dx.doi.org/10.1 080/10942912.2017.1295988. 
Chick, H., Shin, H. S., \& Ustunol, Z. (2001). Growth and acid production by lactic acid bacteria and bifidobacteria grown in skim milk containing honey. Journal of Food Science, 66(3), 478-481. http:// dx.doi.org/10.1111/j.1365-2621.2001.tb16134.x.

Codex Alimentarius Hungaricus. (2004). Fermented dairy foods. In Codex Alimentarius Hungaricus Commission. Milk and Dairy Foods. Directive 2-51 (pp. 21-24). Budapest: Codex Alimentarius Hungaricus Commission.

Coşkun, F., \& Şenoğlu, C. (2011). The effect of using different levels of calcium carbonate on the physical, chemical and sensory properties of yoghurt. The Journal of Food, 36(3), 129-135.

Cruz, A. G., Castro, W. F., Faria, J. A. F., Bolini, H. M. A., Celeghini, R. M. S., Raices, R. S. L., Oliveira, C. A. F., Freitas, M. Q., Conte Júnior, C. A., \& Mársico, E. T. (2013). Stability of probiotic yogurt added with glucose oxidase in plastic materials with different permeability oxygen rates during the refrigerated storage. Food Research International, 51(2), 723-728. http://dx.doi.org/10.1016/j.foodres.2013.01.028.

Cueva, O., \& Aryana, K. J. (2008). Quality attributes of a heart healthy yogurt. Lebensmittel-Wissenschaft + Technologie, 41(3), 537-544. http://dx.doi.org/10.1016/j.lwt.2007.04.002.

Dantas, A. B., Jesus, V. F., Silva, R., Almada, C. N., Esmerino, E. A., Cappato, L. P., Silva, M. C., Raices, R. S., Cavalcanti, R. N., Carvalho, C. C., Sant'Ana, A. S., Bolini, H. M., Freitas, M. Q., \& Cruz, A. G. (2016). Manufacture of probiotic Minas Frescal cheese with Lactobacillus casei Zhang. Journal of Dairy Science, 99(1), 18-30. http://dx.doi. org/10.3168/jds.2015-9880. PMid:26519974.

Dave, R. I., \& Shah, N. P. (1996). Evaluation of media for selective enumeration of Streptococcus thermophilus, Lactobacillus delbrueckii ssp. bulgaricus, Lactobacillus acidophilus and Bifidobacteria. Journal of Dairy Science, 79(9), 1529-1536. http://dx.doi.org/10.3168/jds. S0022-0302(96)76513-X. PMid:8899517.

Demir, G., Süer, O., \& Kaya, S. (2018). Investigation of milk and dairy products consumption of adolescents. Journal of Current Researches on Health Sector, 8(2), 37-48.

Demirci, M., \& Gündüz, H. H. (1994). Dairy Technology Hand Book (p. 184). Istanbul: Hasad Publ.

Demirkaya, A.K., \& Gökalp, C.Z. (2009). The effect of microbial transglutaminase on microbiological, chemical, textural and sensory properties of yogurt. Australian Journal of Dairy Technology, 64(2), 171-176.

Düzgüneş, O., Kesici, T., Kavuncu, O., \& Gürbüz, F. (1978). Research and experiment methods (Statistic Methods II) (Issue No. 1021, p. 381). Ankara: Ankara University Agricultural Department Turkey.

Erejuwa, O. O., Gurtu, S., Sulaiman, S. A., Ab Wahab, M. S., Sirajudeen, K. N., \& Salleh, M. S. (2010). Hypoglycemic and antioxidant effects of honey supplementation in streptozotocininduced diabetic rats. International Journal for Vitamin and Nutrition Research, 80(1), 7482. http://dx.doi.org/10.1024/0300-9831/a000008. PMid:20533247.

Ezz El-Arab, A. M., Girgis, S. M., Hegazy, E. M., \& Abd El-Khalek, A. B. (2006). Effect of dietary honey on intestinal microflora and toxicity of mycotoxins in mice. BMC Complementary and Alternative Medicine, 6(6), 1-13. http://dx.doi.org/10.1186/1472-6882-6-6. PMid:16533410.

Fazilah, N. F., Ariff, A. B., Khayat, M. E., Rios-Solis, L., \& Halim, M. (2018). Influence of probiotics, prebiotics, synbiotics and bioactive phytochemicals on the formulation of functional yoğurt. Journal of Functional Foods, 48, 387-399. http://dx.doi.org/10.1016/j.jff.2018.07.039.

Fonseca, F. G. A., Esmerino, E. A., Filho, E. R. T., Ferraz, J. P., Cruz, A. G., \& Bolini, H. M. A. (2016). Novel and successful free comments method for sensory characterization of chocolate ice cream: A comparative study between pivot profile and comment analysis. Journal of Dairy
Science, 99(5), 3408-3420. http://dx.doi.org/10.3168/jds.2015-9982. PMid:26923040.

Fuller, R. (1989). Probiotics in man and animals. The Journal of Applied Bacteriology, 66(5), 365-378. http://dx.doi.org/10.1111/j.1365-2672.1989. tb05105.x. PMid:2666378.

Garanis-Papadatos, T., \& Katsas, A. (1999). The milk and the honey: ethics of artificial nutrition and hydration of the elderly on the other side of Europe. Journal of Medical Ethics, 25(6), 447-450. http://dx.doi. org/10.1136/jme.25.6.447. PMid:10635496.

Gheldof, N., Wang, X. H., \& Engeseth, N. J. (2002). Identification and quantification of antioxidant component of honeys from various floral sources. Journal of Agricultural and Food Chemistry, 50(21), 5870-5877. http://dx.doi.org/10.1021/jf0256135. PMid:12358452.

Glušac, J., Stijepić, M., Đurđević-Milošević, D., Milanović, S., Kanurić, K., \& Vukić, V. (2015). Growth and viability of Lactobacillus delbrueckii subsp. bulgaricus and Streptococcus thermophilus in traditional yoghurt enriched by honey and whey protein concentrate. Majallah-i Tahqiqat- $i$ Dampizishki-i Iran, 16(3), 249-254. PMid:27175184.

Granato, D., Branco, G. F., Cruz, A. G., Faria, J. A. F., \& Shah, N. P. (2010). Probiotic dairy products as functional foods. Comprehensive Reviews in Food Science and Food Safety, 9(5), 455-470. http://dx.doi. org/10.1111/j.1541-4337.2010.00120.x.

Han, X., Yang, Z., Jing, X., Yu, P., Zhang, Y., Yi, H., \& Zhang, L. (2016). Improvement of the texture of yogurt by use of exopolysaccharide producing lactic acid bacteria. BioMed Research International, 2016, 7945675. http://dx.doi.org/10.1155/2016/7945675. PMid:27294135.

International Diary Federation - IDF. (1997). Yogurt: Enumaration of characteristic microorganisms-colony count technique at $37^{\circ} \mathrm{C}$. (FIL-IDF Standard, Vol. 117B, p. 4). Brussels: International Dairy Federation.

Janiaski, D. R., Pimentel, T. C., Cruz, A. G., \& Prudencio, S. H. (2016). Strawberry-flavored yogurts and whey beverages: What is the sensory profile of the ideal product? Journal of Dairy Science, 99(7), 5273-5283. http://dx.doi.org/10.3168/jds.2015-10097. PMid:27157581.

Kailasapathy, K. (2006). Survival of free and encapsulated probiotic bacteria and their effect on the sensory properties of yoghurt. Lebensmittel-Wissenschaft + Technologie, 39(10), 1221-1227. http:// dx.doi.org/10.1016/j.lwt.2005.07.013.

Kailasapathy, K., \& Rybka, S. (1997). L. acidophilus and Bifidobacterium spp. - their therapeutic potential and survival in yogurt. Australian Journal of Dairy Technology, 52(1), 28-35.

Liem, D. G., Mars, M., \& De Graaf, C. (2004). Sweet preferences and sugar consumption of 4- and 5-year-old children: Role of parents. Appetite, 43(3), 235-245. http://dx.doi.org/10.1016/j.appet.2004.05.005. PMid:15527925.

Lourens-Hattingh, A., \& Viljoen, B. C. (2001). Yogurt as probiotic carrier food. International Dairy Journal, 11(1-2), 1-17. http://dx.doi. org/10.1016/S0958-6946(01)00036-X.

Lucas, A., Sodini, I., Monnet, C., Jolivet, P., \& Corrieu, G. (2004). Probiotic cell counts and acidification in fermented milks supplemented with milk protein hydrolysates. International Dairy Journal, 14(1), 47-53. http://dx.doi.org/10.1016/S0958-6946(03)00147-X.

Machado T. A. D. G., Oliveria, M. E. G., Campos, M. I. F., Assis, P. O. A., Souza, E. L., Madruga, M. S., Pacheco, M. T. B., Pintado, M. M. E., \& Queiroga, R. C. R.E. (2017). Impact of honey on quality characteristics of goat yogurt containing probiotic Lactobacillus acidophilus. LWTFood Science and Technology, 80, 221-229.

Metry Wedad, A., \& Oways, A. A. (2009). Influence of incorporating honey and royal jelly on the quality of yoghurt during storage. Egyptian Journal of Food Science, 37, 115-131. 
Naman, M., Faid, M., \& Adlouni, C. (2005). Microbiological and physicochemical properties of Moroccan honey. International Journal of Agriculture and Biology, 1560(5), 773-776.

Nicholls, J., \& Miraglio, A. M. (2003). Honey and healthy diets. Cereal Foods World, 48(3), 116-119.

Nyawali, B., Chungu, D., Chisha-Kasumu, E., Vinya, R., Chileshe, F., \& Ngandwe, P. (2015). Enzymatic browning reduction in white cabbage (Brassica oleracae) using honey: Does honey color matter. Lebensmittel-Wissenschaft + Technologie, 61(2), 543-549. http://dx.doi. org/10.1016/j.lwt.2014.12.006.

Öğretmen, F., \& İnanan, B. E. (2014). Evaluation of cryoprotective effect of Turkish pine honey on common carp (Cyprinus carpio) spermatozoa. Cryo Letters, 35(5), 427-437. PMid:25397958.

Oliveira, E. W., Esmerino, E. A., Carr, B. T., Pinto, L. P. F., Silva, H. L. A., Pimentel, T. C., Bolini, H. M. A., Cruz, A. G., \& Freitas, M. Q. (2017). Reformulating Minas Frescal cheese using consumers' perceptions: Insights from intensity scales and check-all-that-apply questionnaires. Journal of Dairy Science, 100(8), 6111-6124. http://dx.doi.org/10.3168/ jds.2016-12335. PMid:28551189.

Özer, B. (2006). Yoğurt Bilimi ve Teknolojisi (p. 466). İzmir: Toprak Ofset.

Özer, B. (2010). Fermente Süt Ürünleri, Probiyotik Organizmalar ve Peynir. In N. Aran (Ed.), Gida Biyoteknolojisi (Chap. 8, pp. 220-240). Nobel Yayın No: Ankara.

Özkök, A., D’arcy, B., \& Sorkun, K. (2010). Total phenolic acid and total flavonoid content of Turkish pine honeydew honey. Journal of ApiProduct and ApiMedical Science, 2(2), 65-71. http://dx.doi. org/10.3896/IBRA.4.02.2.01.

Pandey, A., Du, G., Sanromán, M. Á., Soccol, C. R., \& Dussap, C. G. (2017). Current developments in biotechnology and bioengineering: Food and beverages industry. Amsterdam: Elsevier.

Păucean, A., Mudura, E., Jimborean, M. A. M., \& Man, S. (2011). The influence of honey addition on microbiological, physicochemical and sensory characteristics of a kefir-type product during shelf-life. Bulletin of University of Agricultural Sciences and Veterinary Medicine, 68(2), 393-399.

Pereira, E. A. (2003). Rheological behavior of honey from uruçu bee (Melipona scutellaris, L.). Revista Ciências Exatas e Naturais, 5, 179-186.

Popa, D., \& Ustunol, Z. (2011). Sensory attributes of low-fat strawberry yoghurt as influenced by honey from different floral sources, sucrose and high-fructose corn sweetener. International Journal of Dairy Technology, 64(3), 451-454. http://dx.doi.org/10.1111/j.1471-0307.2011.00694.x.

Rasic, J. L., \& Kurmann, J. A. (1978). Fermented fresh milk products and their cultures and yoghurt: Scientific grounds, technology, manufacture and preparations (Vol. 1). Copenhagen: Technical Dairy Publishing House.

Roumyan, N., Zapryanov, P., Kondareva, S., \& Georgiev, G. (1996). On some aspects of a new fermented milk product medina. Biotechnology, Biotechnological Equipment, 10(2-3), 86-89. http://dx.doi.org/10.108 0/13102818.1996.10818904.

Saccaro, D. M., Tamine, A. Y., Pilleggi, A. L. O. P. S., \& Oliveira, M. N. (2009). The viability of three probiotic organisms grown with yoghurt starter cultures during storage for 21 days at $4{ }^{\circ} \mathrm{C}$. International Journal of Dairy Technology, 62(3), 397-404. http://dx.doi.org/10.1111/j.14710307.2009.00497.x.

Santas, L. A. (1979). Marchallina hellenica an important insect for apiculture of Greece. In Proceedings of The 27th International Congress of Apicultur of Apimondia (pp. 419-422). Athens, Greens: Apimondia.

Sanz, M. L., Polemis, N., Morales, V., Corzo, N., Drakoularakou, A., Gibson, G. R., \& Rastall, R. A. (2005). In vitro investigation into the potential prebiotic activity of honey oligosaccharides. Journal of Agricultural and Food Chemistry, 53(8), 2914-2921. http://dx.doi. org/10.1021/jf0500684. PMid:15826039.

Sert, D., Akin, N., \& Dertli, E. (2011). Effects of sunflower honey on the physisochemical, microbial and sensory characteristics in set type yoghurt during refrigerated storage. International Journal of Dairy Technology, 64(1), 99-107. http://dx.doi.org/10.1111/j.14710307.2010.00635.x.

Shah, N. P. (2000). Probiotic Bacteria: Selective enumeration and survival in dairy foods. Journal of Dairy Science, 83(4), 894-907. http://dx.doi. org/10.3168/jds.S0022-0302(00)74953-8. PMid:10791807.

Shah, N. P., \& Lankaputhra, W. E. V. (1997). Improving viability of Lactobacillus acidophilus and Bifidobacterium spp. in yogurt. International Dairy Journal, 7(5), 349-356. http://dx.doi.org/10.1016/ S0958-6946(97)00023-X.

Shah, N. P., Ali, J. F., \& Ravula, R. R. (2000). Populations of Lactobacillus acidophilus, Bifidobacterium spp. and Lactobacillus casei in commercial fermented milk products. Bioscience and Microflora, 19(1), 35-39. http://dx.doi.org/10.12938/bifidus1996.19.35.

Silici, S. (2011). Determination of volatile compounds of pine honeys. Turkish Journal of Biology, 35, 641-645.

Tananaki, C. H., Thrasyvoulou, A., Giraudel, J. L., \& Montury, M. (2007). Determination of volatile characteristics of Greek and Turkish pine honey samples and their classification by using Kohonenself organising maps. Food Chemistry, 101(4), 1687-1693. http://dx.doi.org/10.1016/j. foodchem.2006.04.042.

Tarakçı, Z., Karaağaç, M., \& Çelik, Ö. F. (2015). Determination of fermented dairy product consumption habits in Ordu city center. Academic Journal of Agriculture, 4(2), 71-80.

Torres, F. R., Esmerino, E. A., Carr, B. T., Ferrão, L. L., Granato, D., Pimentel, T. C., Bolini, H. M. A., Freitas, M. Q., \& Cruz, A. G. (2017). Rapid consumer-based sensory characterization of requeijão cremoso, a spreadable processed cheese: Performance of new statistical approaches to evaluate check-all-that-apply data. Journal of Dairy Science, 100(8), 6100-6110. http://dx.doi.org/10.3168/jds.2016-12516. PMid:28571992.

Tosun, F. (2007). The effects of salep on storage stability of yoghurt (Master's thesis). Selçuk University, Graduate School of Natural and Applied Sciences, Department of Food Engineering, Turkey.

Turkish Standards Institution (2006). Yogurt Standard (TS 1330) Turkish Standards Institute, Necatibey cad.112. Turkey: Bakanlıklar Ankara.

Üçüncü, M. (2005). Süt ve Mamülleri Teknolojisi. İzmir: Meta Basım.

Varga, L. (2006). Effect of acacia (Robinia pseudo-acacia L.) honey on the characteristic microflora of yogurt during refrigerated storage. International Journal of Food Microbiology, 108(2), 272-275. http:// dx.doi.org/10.1016/j.ijfoodmicro.2005.11.014. PMid:16478638.

Weerathilake, W. A. D. V., Rasika, D. M. D., Ruwanmali, J. K. U., \& Munasinghe, M. A. D. D. (2014). The evolution, processing, varieties and health benefits of yoğurt. International Journal of Scientific and Research Publications, 4(4), 1-10.

Widyastuti, Y., Rohmatussolihat, \& Febrisiantosa, A. (2014). The role of lactic acid bacteia in milk fermentation. Food and Nutrition Sciences, 5(04), 435-442. http://dx.doi.org/10.4236/fns.2014.54051.

Wu, H., Hulbert, G. J., \& Mount, J. R. (2001). Effects of ultrasound on milk homogenization and fermentation with yogurt starter. Innovative Food Science \& Emerging Technologies, 1(3), 211-218. http://dx.doi. org/10.1016/S1466-8564(00)00020-5. 